\title{
Heart Transplantations Amidst the COVID-19 Pandemic: 'In The Midst of Chaos, There is Also Opportunity'
}

Andrea Amabile ${ }^{1}$ and Arnar Geirsson ${ }^{1}$

${ }^{1}$ Yale University School of Medicine

June 2, 2021

\section{Hosted file}

Commentary JOCS Heart transplant COVID19.docx available at https://authorea.com/users/417034/ articles/524621-heart-transplantations-amidst-the-covid-19-pandemic-in-the-midst-ofchaos-there-is-also-opportunity 